\title{
School Operational Assistance and the Future of Financial Management in the Education Sector
}

\author{
Rudolf Lumbantobing1 \\ DOI: $10.35445 /$ alishlah.v13i3.1442
}

\begin{tabular}{l} 
Article Info \\
\hline Keywords: \\
Analysis, \\
School Operational \\
Assistance, \\
Financial Management
\end{tabular}

Kata kunci:

Analisis,

Bantuan Operasional

Sekolah,

Manajemen Keuangan

\begin{abstract}
This study aims to analyze the School Operational Assistance and the Future of Financial Management in the Education Sector. The approach used in this research is a qualitative method with a descriptive course. The types of data used in this research are primary and secondary data. Preliminary data were obtained from in-depth interviews and questionnaires with informants through purposive sampling technique; the respondents in this research were 65 people, including school administrators and school committees. At the same time, secondary data is obtained from the literature study to acquire and build an abstraction about the research objectives and data support so that general conclusions can be made to specific. This research is conducted on Junior High Schools in West Jakarta, which received School Operational Assistance funds. Based on the results of data analysis, it can be concluded that Junior High Schools in West Jakarta in terms of planning, implementation, and accountability indicators are in the very effective category. This is due to the school's financial management that applies three main strategies, namely Strategic Planning, Strategic Management, and Strategic Thinking.
\end{abstract}

\begin{abstract}
Abstrak
Penelitian ini bertujuan untuk menganalisis Bantuan Operasional Sekolah dan Masa Depan Pengelolaan Keuangan Sektor Pendidikan. Pendekatan yang digunakan dalam penelitian ini adalah metode kualitatif dengan pendekatan deskriptif. Jenis data yang digunakan dalam penelitian ini adalah data primer dan data sekunder. Data awal diperoleh dari wawancara mendalam dan kuesioner dengan informan melalui teknik purposive sampling. Responden dalam penelitian ini adalah 65 orang yang terdiri dari administrator sekolah dan komite sekolah. Sementara itu, data sekunder diperoleh dari studi kepustakaan untuk memperoleh dan membangun abstraksi tentang tujuan penelitian dan pendukung data sehingga dapat dibuat kesimpulan umum ke khusus. Penelitian ini menggunakan dilakukan pada SMP di Jakarta Barat yang menerima dana Bantuan Operasional Sekolah. Berdasarkan hasil analisis data dapat disimpulkan bahwa SMP di Jakarta Barat ditinjau dari indikator perencanaan, pelaksanaan, dan akuntabilitas berada pada kategori sangat efektif. Hal ini disebabkan pengelolaan keuangan sekolah yang menerapkan tiga strategi utama, yaitu Perencanaan Strategis, Manajemen Strategis, dan Pemikiran Strategis.
\end{abstract}

\footnotetext{
${ }^{1}$ Universitas Kristen Krida Wacana

Email: rudolf.tobing@ukrida.ac.id
} 


\section{INTRODUCTION}

Education is a critical component of regional development initiatives that must be prioritized since it produces high-quality human resources that significantly meet contemporary needs (Fitri, 2020). Schools are formal educational institutions that implement a teaching system, consisting of three stages: (1) input, which refers to students who lack specialized knowledge and abilities, (2) transformation, which is the most critical stage in education since it is where the process of learning occurs. At this stage of the Teaching and Learning Activities (KBM), there is a process of coaching and mentoring students to develop specialized skills or knowledge, and (3) the output is the result of the anticipated process (Harliana, 2018). If the teaching process and its numerous facets adhere to a consistent design, it will result in high-quality output from competent resources in a variety of sectors of work (Silele \& Sabijono, 2017; Soulisa, 2017). As the custodian of public policy, the government should enhance the quality of education, conduct studies on the relevance of the vision and mission of education in light of contemporary demands, and provide formal education ranging from elementary school to higher education (Pontoh et al., 2017; Dewi \& Aminah, 2018).

Schools must be prepared on social-institutional and functional-academic levels. On the social-institutional level, this means that elementary schools must be designed so that they function as a place for the socialization process between students, which ultimately fosters and delivers students in the direction of mental and social maturity. On the functional-academic level, this means that all elementary school equipment, such as personnel, curriculum, and other educational materials, must be designed in such a way that they function as a place (Fitri, 2019). This is a critical factor in a nation's progress, as education is a critical component.

In 2018, Indonesia had a Human Development Index of 0.707 and was 111 out of 189 countries and regions. During this period, the life expectancy of Indonesians at birth increased by 9.2 years to 71.5 years, the average length of Schooling rose from 4.7 years to 8 years, and years of Schooling were expected to increase to 12.9 years. Indonesia's Gross National Income (GNI) also increased by around $114.9 \%$, from US $\$ 4,399$ in 1990 to US $\$ 11,256$ in 2019. Various educational programs have been launched by the government to advance the world of education in Indonesia, including the nine-year compulsory education program, free education policies, the provision of school operational assistance funds (School Operational Assistance), and numerous other programs aimed at improving the quality of education in Indonesia. The provision of school operational support funds or school active assistance money is one of the numerous programs initiated by the government and is still operating today (Wahyudi, 2021; Ismail \& Sumalia, 2020).

Every citizen between the ages of seven and fifteen is required to attend basic education under Law No. 20 of 2003. Additionally, article 34, paragraph 2 states that the central government and local governments are responsible for ensuring that compulsory education at the minimum level of basic education is provided free of charge. Article 34, paragraph 3 states that education is the state's responsibility and is organized through educational institutions (schools) (Uviyanti \& Scouts, 2020). As mandated by the legislation, the government and local governments are required to provide educational services to all pupils in elementary school and other academic units of equivalent significance.

As part of the implementation of these regulations, the government, as the policyholder, establishes a school operational assistance program based on the principle stated in the Minister of Education and Culture of the Republic of Indonesia's Number 76 of 2012, concerning Technical Guidelines for the Use and Accountability of Financial Funds for School Operational Assistance in 2013. As explained in 2013, School Operational Assistance (Aid) School Operations) is a government program that is essentially a grant program (Komariah, 2018; Syaifullah, 2021). Additionally, nonpersonnel expenditures include the costs of consumable instructional materials or equipment, as well as indirect costs such as power, water, communication services, facility and infrastructure maintenance, overtime pay, transportation, consumption, taxes, and insurance (Hasibuan, 2021). On the other hand, some types of investment and personnel funding are permitted to be sponsored 
through School Operational Assistance funds. According to the technical manual for the use of school operational assistance funds and financial reports on active school assistance, the School Operational Assistance program aims to alleviate the community's financial burden for education within the framework of a quality nine-year compulsory education (Zabua, 2020).

Improving the quality of education is not an easy task because it involves technical issues and a variety of extremely complicated and complex issues, including planning, funding, and the efficiency and effectiveness with which the school system is implemented. In other words, the school management is one of the major factors affecting the quality of education (Alfiah et al., 2021). To provide high-quality education, it is vital to handle educational institutions' available resources comprehensively and professionally. Financial resources are one of the resources that educational institutions must handle effectively. Finance is a term that refers to the finances that schools require to complete various learning facilities and infrastructure, improve teacher welfare and service, and execute supervisory programs (Megawaty et al., 201). As educational leaders, principals must understand and manage school finances effectively while also being accountable and transparent to the community and government.

\section{METHODS}

The approach used in this research is a qualitative method with a descriptive course. The types of data used in this research are primary data and secondary data. Preliminary data were obtained from in-depth interviews and questionnaires with informants through purposive sampling technique; the respondents in this research were 65 people, including school administrators and school committees. At the same time, secondary data is obtained from literature studies to acquire and build an abstraction about the research objectives and data support so that general to specific conclusions can be made (Alexandru \& Matei, 2019). This research was conducted at Junior High Schools in West Jakarta, which received School Operational Assistance funds.

\section{FINDINGS AND DISCUSSION}

Based on the data obtained regarding the school financial management system in the use of school operational assistance and the fulfillment of educational facilities and infrastructure, it is implemented in the following ways:

\section{School Budget Planning}

Budgeting for Junior High Schools in Jakarta is prepared in a statement about the estimated performance achieved over a certain period and is expressed in financial terms. The planning is arranged systematically and is valid for a long period. The budget planning process for junior high school infrastructure in West Jakarta begins with a joint meeting involving leaders, teacher councils, school committees, and foundations to plan the needs of facilities for one academic year. The conference will result in decisions relating to evaluating existing facilities and infrastructure, arranging the procurement of facilities by considering the priority scale, and implementing the plan through the procurement of the required facilities and infrastructure. The draft budget for the fulfillment of facilities and infrastructure and the allocation of school operational assistance funds will be determined in the School Income and Expenditure Plan.

The planning budget for the infrastructure cost is described per item with the foundations, schools, and committees, which are prepared based on mutual agreement. Every semester, of course, there is a check for goods that can still be used and are not suitable for use, so there will be the procurement of facilities that have been used up or are not ideal for use. Likewise, with infrastructure, if there is damage, of course, it will be repaired. In determining the budget allocation, it is necessary to consider the urgency of the activity needs. This concerns the issue of time, personnel, and the amount of available fund allocation. So there needs to be an analysis of the sources of funds and the nominal that the institution may get for each scheduled activity. In practice, sources of funds in school activities produce a School Budget Work Plan. Financial 
planning in fulfilling junior high school facilities and infrastructure in West Jakarta is presented in the following figure:

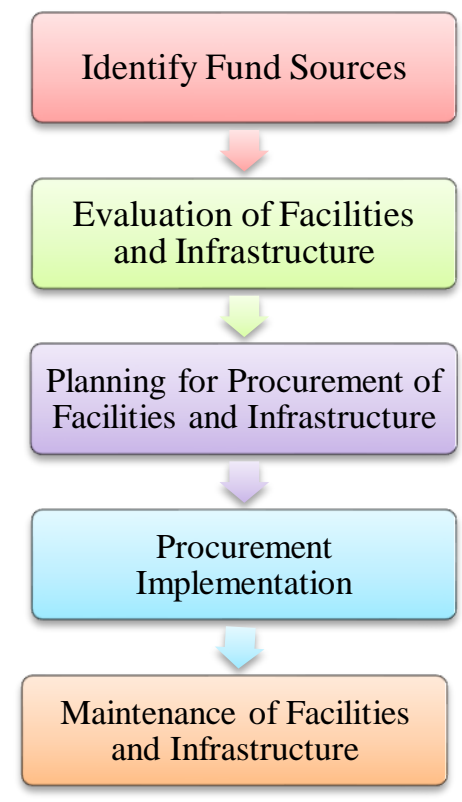

Figure 1. School Financial Planning in fulfilling facilities and infrastructure

In the implementation of education, the source of funds is a very decisive potential for the success or failure of an educational institution; therefore, an appropriate financial management system is needed. As an initial part of financial management activities. Budgeting is a planning step and a fundamental planning instrument. The budget is the overall breakdown of costs regarding school revenues and expenditures, generally prepared annually by the institution by involving related parties, as a planning and control tool. The budget preparation is a description of each activity planned by the school to determine the unit costs for each exercise to assist educational institutions in implementing their actions. The budget functions are classified into three types: First, an interpreter tool, which estimates the amount of expenditure and income to know the need for funds needed in the realization of activities in educational institutions. Second, the instrument of authority, namely giving power regarding the funds issued to finance activities according to budget planning. Third, efficiency tools, namely knowing educational activities carried out according to budget planning efficiently.

School financial planning refers to the concept of implementing school education as a whole. Services in educational institutions include 1) educative service techniques in the process of teaching and learning activities both in theory and practice and assessment of learning outcomes, 2) services that support the operation of extracurricular and extracurricular activities, 3) maintenance and utilization of textbooks, educational tools, learning tools , laboratories, libraries and practical equipment as well as practice materials and skills, 4) procurement and maintenance of supporting facilities such as administrative facilities, school buildings, classrooms, school facilities and the environment; 5) provision of resources and services, 6) official travel of madrasa heads and teachers, 7) empowerment of madrasah committees, social activities, and community services; 8) competition activities participated in by students or teachers, 9) school service needs that are used up such as newspapers, 10) honorarium for educators and education staff, health insurance, transportation, and others (Mappadang, 2021). 


\section{Implementation of School Operational Assistance Funds}

The management of School Operational Assistance monies must be agreed upon and ratified by the School Operational Assistance Management Team, the teacher council, and the School Committee. It must be included as an income source in the School Income and Expenditure Plan and funded through the Regional Government or other lawful sources. The agreement made regarding the use of School Operational Assistance funds (and any other funds) must be documented in writing via meeting minutes signed by all meeting participants. This is consistent with Osuji and Queen's (2021) findings that the school budget affects student results. Budget expenditures in education cannot be regarded as exogenous variables due to the fact that numerous school characteristics affect both school budgets and student outcomes.

Meanwhile, in addition to the thirteen items in the School Operational Assistance fund's administration, other expenses include building fees paid by students and social contributions for each instructor. The efficacy of School Operational Assistance Fund Management (School Operational Assistance) at Junior High Schools in West Jakarta as measured by planning indicators. The following table summarizes the findings of an investigation of the effectiveness of the Management of School Operational Assistance (School Operational Assistance) finances at Junior High Schools in West Jakarta in 2020, using planning indicators:

Table 1. The results of respondents' answers are based on planning indicators

\begin{tabular}{ccccccc}
\hline No & Respondent & Score & $\begin{array}{c}\text { Total } \\
\text { Score }\end{array}$ & $\begin{array}{c}\text { Ideal } \\
\text { Score }\end{array}$ & Percentage & Criteria \\
\hline 1 & 8 & 29 & 204 & 210 & $97 \%$ & Very effective \\
2 & 26 & 29 & 702 & 755 & $93 \%$ & Very effective \\
3 & 14 & 28 & 352 & 395 & $90 \%$ & Very effective \\
4 & 7 & 27 & 157 & 185 & $88 \%$ & Very effective \\
5 & 5 & 26 & 102 & 125 & $85 \%$ & Very effective \\
6 & 1 & 25 & 33 & 35 & $80 \%$ & Very effective \\
7 & 4 & 25 & 26 & 60 & $78 \%$ & Very effective \\
Total & 65 & & & & $92 \%$ & Very effective \\
\hline
\end{tabular}

Source: data proceed

Based on the data in the table above, it can be seen that 65 respondents stated that the First High School in West Jakarta was included in the very effective criteria. Effectiveness of School Operational Assistance Fund Management (School Operational Assistance) at Junior High Schools in West Jakarta, based on implementation indicators. The results of the analysis of the effectiveness of the Management of School Operational Assistance (School Operational Assistance) funds at Junior High Schools in West Jakarta, based on implementation indicators, can be seen in Table 2 as follows:

Table 2. The results of respondents' answers are based on implementation indicators

\begin{tabular}{ccccccc}
\hline No & Respondent & Score & $\begin{array}{c}\text { Total } \\
\text { Score }\end{array}$ & $\begin{array}{c}\text { Ideal } \\
\text { Score }\end{array}$ & Percentage & Criteria \\
\hline 1 & 4 & 15 & 43 & 45 & $93 \%$ & Very effective \\
2 & 15 & 14 & 184 & 212 & $88 \%$ & Very effective \\
3 & 32 & 13 & 373 & 467 & $80 \%$ & Very effective \\
4 & 14 & 12 & 112 & 155 & $74 \%$ & Very effective \\
Total & 65 & & 714 & 879 & $82 \%$ & Very effective \\
\hline
\end{tabular}

Source: data proceed

Based on the data above, it can be seen that four respondents with a score of 15 are included in the effective criteria, 15 respondents with a score of 14 are included in the effective standards. Management of school operational assistance funds at junior high schools in West Jakarta, when viewed from the implementation indicators, the overall score of $714(82 \%)$ is in the very effective criteria. 
The results of the analysis of the effectiveness of the Management of School Operational Assistance (School Operational Assistance) funds at Junior High Schools in West Jakarta, based on accountability indicators, can be seen in Table 3 as follows:

Table 3. The results of respondents' answers are based on accountability indicators

\begin{tabular}{ccccccc}
\hline No & Respondent & Score & $\begin{array}{c}\text { Total } \\
\text { Score }\end{array}$ & $\begin{array}{c}\text { Ideal } \\
\text { Score }\end{array}$ & Percentage & Criteria \\
\hline 1 & 21 & 20 & 343 & 365 & $95 \%$ & Very effective \\
2 & 18 & 19 & 289 & 325 & $90 \%$ & Very effective \\
3 & 12 & 18 & 172 & 215 & $85 \%$ & Very effective \\
4 & 10 & 17 & 129 & 162 & $82 \%$ & Very effective \\
5 & 7 & 16 & 92 & 123 & $75 \%$ & Very effective \\
Total & 65 & & & & $88 \%$ & Very effective \\
\hline
\end{tabular}

Source: data proceed

Based on the data in the table, it can be concluded that the management of School Operational Assistance funds on the accountability indicators can be completed as being very effective. The management of the School Operational Assistance funds refers to the Regulation of the Minister of Education and Culture of the Republic of Indonesia Number 76 of 2012 concerning Technical Guidelines for the use and financial accountability of the 2020 School Operational Assistance funds. Indicators, namely planning, implementation, and responsibility of all hands in the very effective category. With a total indicator percentage of $87 \%$. According to the Ministry of National Education, the management of School Operational Assistance funds is very effective if it reaches the criteria above $70 \%$.

Planning indicators with a large percentage of $91 \%$ are very effective. With effective School, Operational Assistance Fund management planning will certainly result in good realization. The initial step taken by schools in managing School Operational Assistance funds is planning, in which there is a process of defining organizational goals, making strategies to achieve goals, and developing corporate work activity plans, which are summarized in the Activity Plan and School Budget in managing School Operational Assistance funds. The implementation indicators with a large percentage of $81 \%$ are in the very effective category. To implement all the plans and policies that have been made previously in the RKAS to achieve the targets of the School Operational Assistance program that have been set. The accountability indicator with a large percentage of $88 \%$ is in the very effective category, indicating that elementary schools can do everything regulated by Permendiknas No. 76. Summarize the Technical Guidelines for the Use and Financial Accountability of School Operational Assistance funds in a report.

The Manager/Head of School Finance is obliged to determine school finances, obtain funds for school infrastructure, and use these funds to finance school needs. What must be owned by the Head of Finance, namely: a financial strategy. These strategies include a) Strategic Planning, guided by internal linkages and external needs from outside. It contains elements of needs analysis, projection, forecasting, economics, and finance; b) Strategic Management, Efforts to manage the change process, such as planning, strategic, organizational structure, control, strategic and primary needs; and c) Strategic Thinking, as a basic framework for formulating goals and results on an ongoing basis.

Financial accountability Junior high school in West Jakarta is understood as the responsibility carried out by a person for all his actions - especially those related to finances to the person who gives authority. Based on the plan that the school has determined, the school spends money to fulfill school facilities and infrastructure responsibly. It is reported to the principal, foundation, parents, community, and government. 
According to the research results conducted by Wang (2021), school financial accountability in the fulfillment of educational infrastructure is in the daily cash book made by the school treasurer. This economic control book is submitted to the principal and stakeholders at the school year's monthly, quarterly, and final meetings. Likewise, Mas \& Sahada's (2019) narrative, accountability reporting in schools is carried out at the end of the year by presenting students' guardians. And at the end of the school year, the RAPBS for educational infrastructure is discussed with the foundation, school committee, and the school for accountability for compliance with budget planning.

Based on the observations of researchers in the field, it was found that the treasurer carries out the financial responsibility of schools on a small scale by reporting the financial condition to the principal. While accountability on a large scale, financial statements. The implementation of financial management adheres to the segregation of duties between authorization, ordinator, and treasurer. Authorizers are officials who are authorized to take actions that result in budget receipts and expenditures. Ordinator is authorized to conduct testing and order payment for all actions taken based on the established authority. The principal, as a manager, functions as authorization and is entrusted with the function of an ordinator to order payments (Andiawati, 2017). However, it is not justified to carry out the position of the treasurer because he is obliged to carry out internal supervision. In addition to having the functions of a treasurer, the treasurer is also entrusted with the process of an ordinator to test the right to payment.

\section{CONCLUSION}

Based on the results of data analysis, it can be concluded that Junior High Schools in West Jakarta in the indicators of planning, implementation, and accountability are in the very effective category. This is due to the school's financial management that applies three main strategies, namely Strategic Planning, Strategic Management, and Strategic Thinking.

\section{REFERENCES}

Alexandru, I. M., \& Matei, G. (2019). Financial Management of the Romanian Preuniversitary Education Institutions. Finance: Challenges of the Future, 19(21).

Alfiah, S., Rachman, F., Janudin, J., Dwianggoro, P., \& Anhary, A. S. (2021). Pengelolaan Manajemen Keuangan Dalam Pindidikan Yayasan Ini Media Kita. Abdi Laksana: Jurnal Pengabdian Kepada Masyarakat, 2(1), 60-66.

Aliyu, B. B. (2018). Assessment of financial management practices among secondary school principals, Kaduna State. International Journal of Hospitality \& Tourism Management, 2(2), 22-27.

Alkurnia, R., \& Anggraini, A. (2017, March). Pengelolaan Manajemen Keuangan Pada Lembaga Pendidikan (Studi Pada Sekolah Al-Islam Dan Muhammadiyah Di Surakarta). In Prosiding Seminar Pendidikan Ekonomi dan Bisnis (Vol. 3, No. 1).

Andiawati, E. (2017, April). Pengelolaan Keuangan Lembaga Pendidikan/Sekolah. In Prosiding Seminar Pendidikan Ekonomi Dan Bisnis (Vol. 3, No. 1).

Bakar, M. Z. A., \& Bakar, S. A. (2020). Prudent financial management practices among Malaysian youth: The moderating roles of financial education. The Journal of Asian Finance, Economics, and Business, 7(6), 525-535.

Barr, M. J., \& McClellan, G. S. (2018). Budgets and financial management in higher education. John Wiley \& Sons.

Dewi, R. M., \& Aminah, A. (2018). Pelatihan Manajamen Dan Administrasi Keuangan Sekolah Di Tk 'Aisyiyah Tangerang Selatan. Prosiding Sembadha, 1, 177-179.

Fitri, A. (2019). Manajemen Kepala Sekolah dalam Pengelolaan Dana Bantuan Operasional Sekolah (Bos) pada Smp Negeri di Kota Banda Aceh. Jurnal Administrasi Pendidikan: Program Pascasarjana Unsyiah, 7(1). 
Fitri, A. (2020). Pengelolaan Dana Bantuan Operasional Sekolah (BOS) Sekolah Dasar Negeri Kecamatan Mandiangin Koto Selayan Kota Bukittinggi.Jurnal Bahana Manajemen Pendidikan, 2(1), 33-39.

Hasibuan, A. R. D. (2021). Penerapan Tata Kelola Keuangan Pendidikan Sekolah Dasar Pada Akhir Periode Tahun 2020. Juripol (Jurnal Institusi Politeknik Ganesha Medan), 4(1), 304-309.

Herliana, C. L. (2018). Evaluasi Sistem Informasi Akuntansi Penerimaan Dan Pengeluaran Dana Bantuan Operasional Sekolah (BOS) di SMA PGRI PURI Kabupaten Mojokerto. PRIVE: Jurnal Riset Akuntansi Dan Keuangan, 1(2), 98-104.

Ifeanyichukwu, U. G. W. U., Gladys, O., \& Agu, A. N. (2020). Analysis Of Financial Management Activities Of Secondary School Principals In Anambra State; Focus On Budgeting. National Journal Of Educational Leadership, 5(2).

Ismail, F., \& Sumaila, N. (2020). Implementasi Manajemen Pembiayaan dalam Pengelolaan Dana Bantuan Operasional Sekolah (BOS) di Madrasah Aliyah Negeri 1 Bitung, Sulawesi Utara. MANAGERIA: Jurnal Manajemen Pendidikan Islam, 5(1), 1-18.

Komariah, N. (2018). Konsep Manajemen Keuangan Pendidikan. Al-Afkar: Jurnal Keislaman \& Peradaban, 6(1), 67-94.

Mappadang, A. (2021). The Productivity of Vocational Schools: The Role of Efficiency, Fairness, Transparency, and Accountability of Financial Management. Widyakala: Journal of Pembangunan Jaya University, 8(1), 1-9.

Mas, S. R., \& Sahada, M. A. (2019, December). A Financial Management Application Approach towards "Industry 4.0 Revolutionary Era" in Islamic Boarding High School of Insan Cendekia Gorontalo. In 5th International Conference on Education and Technology (ICET 2019) (pp. 134-136). Atlantis Press.

Megawaty, D. A., Setiawansyah, S., Alita, D., \& Dewi, P. S. (2021). Teknologi dalam pengelolaan administrasi keuangan komite sekolah untuk meningkatkan transparansi keuangan. Riau Journal of Empowerment, 4(2), 95-104. 